\title{
Effects of Human Activities in the Wei River Basin on the Lower Yellow River, China
}

\author{
Li He \\ Key Laboratory of Water Cycle and Related Land Surface Processes, Institute of Geographic Sciences \\ and Natural Resources Research, Chinese Academy of Sciences, 100101 Beijing
}

Received: 15 March 2017

Accepted: 22 April 2017

\begin{abstract}
Water and soil conservation practices in the Wei River Basin (WRB) may influence the Lower Wei River (LWR) itself and the Lower Yellow River (LYR), of which the Wei is a tributary. Based on data of measured and natural runoff and suspended sediment load (SSL) in the WRB, the connections between runoff and SSL from the WRB and deposition in the LWR, the elevation of Tonggguan Hydrology Station, and deposition in the LYR are analyzed. For the compound effects of human activity and climate change in the WRB, the amount of deposition reduction in the LWR during 2000-2009 is about three times what it decreased during 1970-1979. For per square kilometers of soil conservation, the effect of human activities in the WRB on deposition in the LWR during period of 2000-09 is about four times that of the period of 1970-1979. As decreased runoff and SSL from the WRB, deposition in the LYR decreased during the periods of 1970-1979 and 1990-1999, while deposition in the LYR increased during the periods of 1980-1989 and 2000-2009. For the planned reservoir in the Jing River Basin, the decreased deposition in the LYR may be smaller than that of the LWR.
\end{abstract}

Keywords: runoff, suspended sediment load, human activities, the Wei River Basin, the Lower Yellow River

\section{Introduction}

The Wei River (WR) is the largest tributary of the Yellow River (YR), and the upper drainage areas of its two main tributaries, the Beiluo River and the Jing River, are part of the Coarse Sediment Area (CAS). The "Grain for Green" project, which aims to increase the vegetable coverage on steep hillsides of CAS, has been carried out by the Chinese government since 1999 [1]. The average sediment delivery modulus in the CSA decreased from

*e-mail: heli@igsnrr.ac.cn
$7,767.4 \mathrm{t} /\left(\mathrm{km}^{2} \cdot \mathrm{a} ; 1951-69\right)$ to $980.5 \mathrm{t} /\left(\mathrm{km}^{2} \cdot \mathrm{a} ; 2000-10\right)$ [2]. Stream fow and suspended sediment load (SSL) show dramatic downward trends since increasingly employing soil preservation measures and soil-erosion-reduction projects. The amount of average annual SSL into the YR delivered by the WR decreased from $16 \times 10^{8} \mathrm{t}(1919-$ $1960)$ to $6.53 \times 10^{8} \mathrm{t}(1961-2000)$, and it further decreased to $1.51 \times 10^{8} \mathrm{t}(2000-2005)$ [1, 3-5].

Variation of runoff and SSL and the contribution of multiple factors (human activities and climate change) to the variation in Wei River [6-16] and tributaries [1720] local drainage areas have been analyzed widely. The changed sediment and water discharge in upper drainage areas may also influence the fluvial process of the lower 
channel, as the river system is closely connected. And the relationship between deposition in the LYR and the amount of runoff and SSL from different upper regions has been widely discussed [21-25]. While work investigating the relationship between human activities in upper drainage areas and its effects on the stem channel of the LYR, it may also benefit the management of the LYR except the local drainage area. Ran [11-12] analyzed the effects of human activities in the drainage area of WRB on the LYR. And the relationship between these two parts are simplified as deposition in the LYR may decrease $0.7 \mathrm{t}$ with $1 \mathrm{t}$ of reduced SSL from the WRB. However, this relationship is much more complex according to the empirical formula of the LYR [26-28]. A better understanding of the temporal changes of runoff and SSL is very useful for soil and water conservation, eco-rehabilitation, and river basin management.

And the purpose of this paper is detecting the relationship between decreased runoff and SSL by human activities in WRB on the LYR. So measured and natural runoff at the WRB (Xianyang, Zhuangtou, and Zhangjiashan hydrology stations) are first collected. Moreover, the planned reservoir of Dongzhuang may be located on the Jing River, and the effects of the planned reservoir on the WR and the LYR are also considered. Based on the reservoir design index and the management scheme, the influence of the planned reservoir on the runoff and SSL from the Jing River can also be estimated. Based on all these collected data, the influence of human activities in the WRB on the WRB and LYR are analyzed based on empirical formulas.

\section{Material and Methods}

\section{The Drainage Area}

The WR is the largest tributary of the YRB. The drainage area of the WRB is $13 \times 10^{4} \mathrm{~km}^{2}$, and the length is about $818 \mathrm{~km} \mathrm{[8].} \mathrm{The} \mathrm{mean} \mathrm{annual} \mathrm{stream} \mathrm{flow} \mathrm{and}$ SSL of the WRB to the YR are $74.5 \times 10^{8} \mathrm{~m}^{3}$ and $3.88 \times 10^{8} \mathrm{t}$ (data between 1956 and 2010), respectively [8]. Sediment transported into the YR from the WRB account for $35-40 \%$ of the total SSL of the YRB. The average annual water runoff and SSL of Huaxian Hydrology station are about $72.12 \times 10^{8} \mathrm{~m}^{3}$ (data from 1950-2000) and $3.57 \times 10^{8} \mathrm{t}$ (data from 1950-2000), respectively.

Drainage areas in the north and south of the stem channel of the WR belong to the Loess Plateau and Qinling Mountain area, respectively. Two major tributaries in the north are the Jing and Beiluo rivers (Fig. 1a), and drainage areas of these two tributaries are a major part of the northern drainage area of WRB. Sediment erosion in the northern drainage area of WRB is relatively serious, i.e., the erosion modulus of the Jing River is about $6,580 \mathrm{t} / \mathrm{km}^{2}$ (data between 1958 and 1973). The area with extensive soil erosion of the WRB is about $10.4 \times 10^{4} \mathrm{~km}^{2}$ $\left(4.5 \times 10^{4} \mathrm{~km}^{2}\right.$ of the main stream, $3.95 \times 10^{4} \mathrm{~km}^{2}$ of the Jing River, and $1.9 \times 10^{4} \mathrm{~km}^{2}$ of the Beiluo River), and it

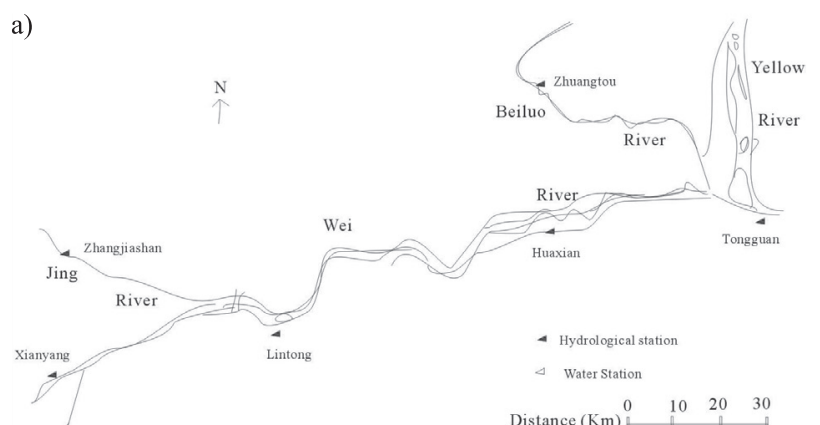

b)
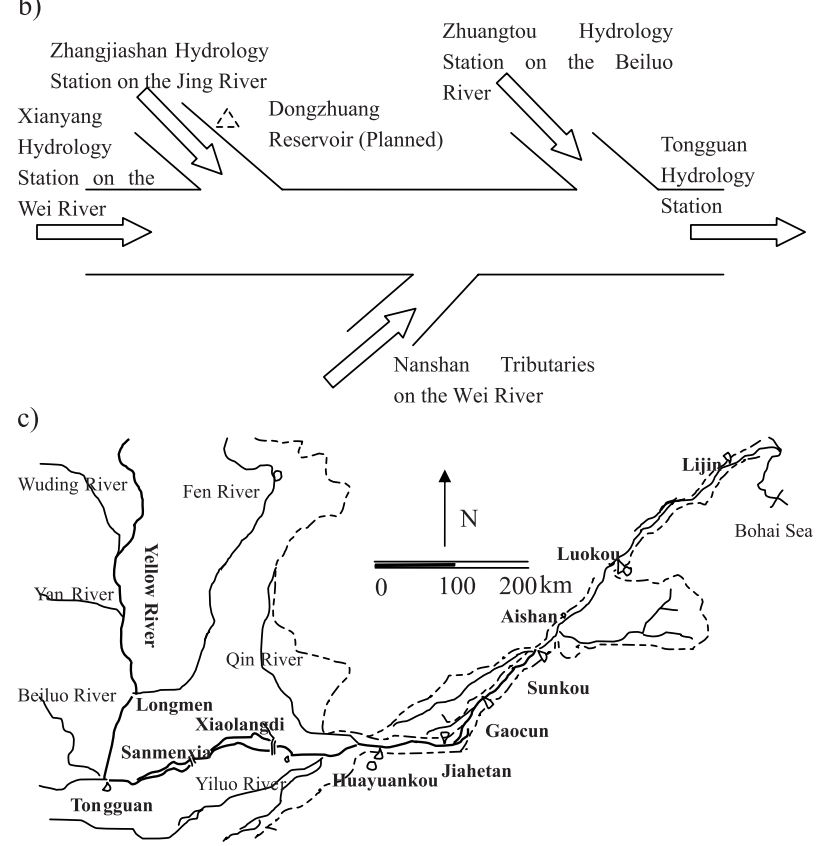

Fig. 1. Sketch maps of the Lower Wei River and the Lower Yellow River. a) Stem channel and tributaries of the Lower Wei River, b) Sketch map of the Lower Wei River, c) The Lower Yellow River.

counts for approximately $77 \%$ of the drainage area of the WRB [8].

The controlling area of Huaxian Hydrology Station (located at the stem channel of WR), Zhangjiashan Hydrology Station (located at the stem channel of the Jing River), and Zhuangtou Hydrology Station (located at the stem channel of the Beiluo River) are about $10.6 \times 10^{4}$ $\mathrm{km}^{2}, 4.3 \times 10^{4} \mathrm{~km}^{2}$, and $2.6 \times 10^{4} \mathrm{~km}^{2}$, respectively (Table 1 ). And SSL measured at Huaxian and Zhuangtou can be used to represent the total sediment eroded in the WRB (Fig. 1a). There are other inflows from the southern drainage area, as shown in Fig. 1b, and these tributaries are called Nanshan Tributaries. Besides, there is a planned reservoir called Dongzhuang Reservoir, which is planned on the stem channel of the Jing River (Fig. 1b).

For the Lower Yellow River, depositions of two reservoirs (the Sanmenxia and the Xiaolangdi) are not considered (Fig. 1c). This means that the influence of these two reservoirs on the SSL entering the LYR is ignored, and all reduced SSL and runoff from the WRB can be transmitted into the lower channel directly. For 
Table 1. Statical characteristics of the Wei, Jing, and Beiluo rivers.

\begin{tabular}{|c|c|c|c|c|c|c|c|c|c|}
\hline & \multirow{2}{*}{$\begin{array}{c}\text { Length } \\
\text { of stem } \\
\text { River } \\
(\mathrm{Km})\end{array}$} & \multirow{2}{*}{$\begin{array}{c}\text { Drainage } \\
\text { area } \\
\left(\times 10^{4} \mathrm{~km}^{2}\right)\end{array}$} & Station name & $\begin{array}{c}\text { Controlling station } \\
\text { area } \\
\left(\times 10^{4} \mathrm{Km}^{2}\right)\end{array}$ & $\begin{array}{c}\text { Drainage } \\
\text { area with } \\
\text { serious } \\
\text { erosion } \\
\left(\mathrm{Km}^{2}\right)\end{array}$ & $\begin{array}{c}\text { Precipitation } \\
(\mathrm{mm})\end{array}$ & $\begin{array}{c}\text { Water } \\
\text { Runoff } \\
\left(10^{8} \mathrm{~m}^{3}\right)\end{array}$ & $\begin{array}{c}\text { SSL } \\
\left(10^{8} \mathrm{t}\right)\end{array}$ & data \\
\hline Wei River & 818 & 6.32 & Huaxian & 10.6 & -- & 613.4 & 72.12 & 3.57 & $1950-2000$ \\
\hline Jing River & 455 & 4.54 & Zhangjiashan & 4.3 & 1.24 & 532.7 & 13.44 & 2.03 & $1987-2005$ \\
\hline Beiluo River & 680 & 2.69 & Zhuangtou & 2.6 & 0.63 & 514.2 & 7.4 & 0.68 & $1987-2005$ \\
\hline
\end{tabular}

the river reach between Huayuankou and Lijin, sediment deposition can be estimated by an empirical formula.

\section{Effects of Human Activities on River Segments}

The contribution of human activities in the WRB on the deposition in the LYR can be estimated by processes shown in Fig. 2:

1) Measured runoff and SSL.

Measured runoff and SSL at the two stations are collected (Huaxian and Zhuangtou) as the runoff and SSL from the Jing River has been considered in the Huaxian. Huaxian hydrology station, which is located at the stem channel of the WR, is the controlling station of the WR. The controlling area of Huaxian Hydrology station accounts for more than $80 \%$ of the WRB, and the ratio of runoff measured at Huaxian Hydrology Station is approximately $90 \%$. Zhuangtou Hydrology Station is the controlling station of the Beiluo River, the second largest tributary of the WR. These two hydrology stations are normally adopted to represent the characteristics of these two rivers. Data measured during 1956-2010 are collected, which are measured and published by the Yellow River Conservancy Commission (YRCC).

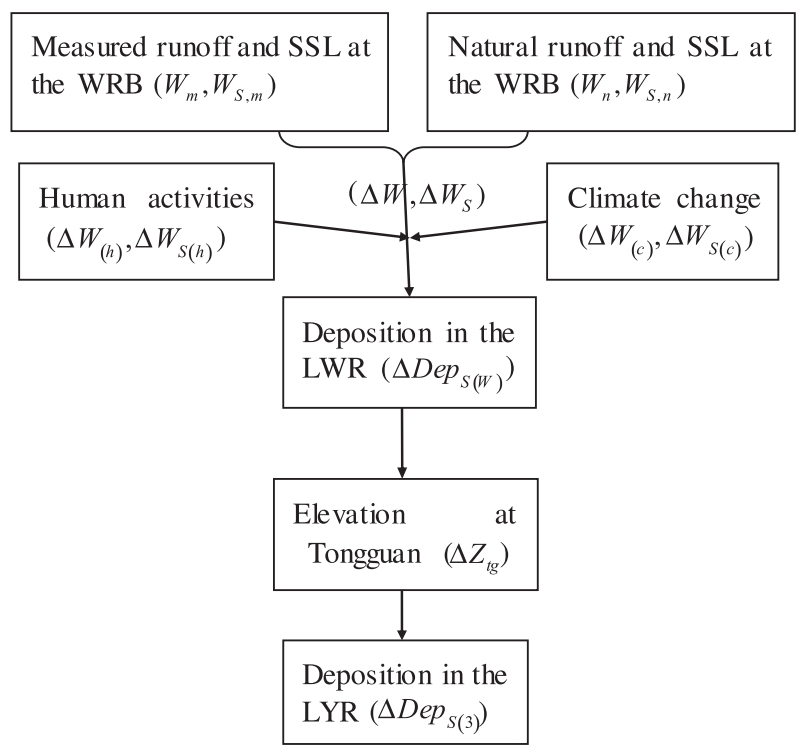

Fig. 2. Sketch map of the estimating procedure.
2) Estimation of natural runoff and SSL.

The discrepancy between measured and natural data is composed of agricultural irrigation, industrial and domestic water consumption, flood diversion, and water storage by soil and water conservation measure [8, 29-31]. The discrepancy can be estimated as:

$$
\begin{gathered}
W_{n}=W_{m}+\Delta W \\
W_{S, n}=W_{S, m}+\Delta W_{S}
\end{gathered}
$$

...where $\Delta W$ and $\Delta W_{s}$ are the total amount of decreased water runoff $\left(10^{8} \mathrm{~m}^{3}\right)$ and SSL $\left(10^{8} \mathrm{t}\right)$, respectively; $W_{n}$ and $W_{S, n}$ are the natural values of water runoff $\left(10^{8} \mathrm{~m}^{3}\right)$ and SSL $\left(10^{8} \mathrm{t}\right)$, respectively; and $W_{m}$ and $W_{S, m}$ are the measured values of water runoff $\left(10^{8} \mathrm{~m}^{3}\right)$ and SSL $\left(10^{8} \mathrm{t}\right)$, respectively. The YRCC measured water consumption for irrigation, flood protection, and water stored in reservoirs, and also water diversion from the river to basin [31]. However, water volumes abstracted for industrial and domestic consumption are not measured by the YRCC [31]. Soil conservation measures mainly considered are practices with a form of level terrace, afforestation, grassland, and check dam.

3) Contribution of human activities.

Human intervention (e.g., soil and water conservation measures) and climate change (e.g., temperature and precipitation) have been responsible for the dramatically decreasing streamflow and sediment yield in the middle and lower reaches of the YR [32]. Direct human activities mainly include soil and water conservation and increasing water demand, whereas indirect activities refer to land cover and land use changes. The amount of runoff and SSL by human activities and climate change are

$$
\begin{gathered}
\Delta W=\Delta W_{(h)}+\Delta W_{(c)} \\
\Delta W_{S}=\Delta W_{S(h)}+\Delta W_{S(c)}
\end{gathered}
$$

...where $\Delta W_{(h)}$ and $\Delta W_{(c)}$ are the contributions by human activity and climate change, respectively $\left(10^{8} \mathrm{~m}^{3}\right)$; and $\Delta W_{S(h)}$ and $\Delta W_{S(c)}$ are the contributions by human activity and climate change, respectively $\left(10^{8} \mathrm{t}\right)$. For the watershed of the WR, human activities may contribute a certain ratio 
Table 2. Contribution rates of human activities and climate change for discharge reduction.

\begin{tabular}{|c|c|c|c|c|c|}
\hline \multirow{2}{*}{ Study area } & \multicolumn{2}{|c|}{ Data } & \multirow{2}{*}{$\begin{array}{l}\text { Impact by human activities } \\
\text { (\%) }\end{array}$} & \multirow{2}{*}{$\begin{array}{l}\text { Impact by climate change } \\
\qquad(\%)\end{array}$} & \multirow{2}{*}{ Reference } \\
\hline & Benchmark & Changed period & & & \\
\hline YRB & \multicolumn{2}{|c|}{$1970-2008$} & 83.0 & 17.0 & {$[5]$} \\
\hline YRB & \multicolumn{2}{|c|}{$2000-08$} & 55.0 & 45.0 & {$[34]$} \\
\hline YRB & $1919-86$ & $2000-12$ & 43.4 & 56.6 & {$[35]$} \\
\hline YRB & \multicolumn{2}{|c|}{$1951-2010$} & 76 & 24 & {$[36]$} \\
\hline YRB & $1950-79$ & $1980-89$ & 46.6 & 53.4 & {$[37]$} \\
\hline \multirow{2}{*}{ WRB } & \multirow{2}{*}{$1956-70$} & $1971-92$ & $33.07-96.00$ & $4.00-66.93$ & \multirow{2}{*}{ [8] } \\
\hline & & $1993-2010$ & $75.99-89.50$ & $10.50-24.01$ & \\
\hline \multirow{4}{*}{ WRB } & \multirow{4}{*}{$1956-70$} & $1970 \mathrm{~s}$ & 64 & 36 & \multirow{4}{*}{ [9] } \\
\hline & & $1980 \mathrm{~s}$ & 72 & 28 & \\
\hline & & $1990 \mathrm{~s}$ & 47 & 53 & \\
\hline & & $2000 \mathrm{~s}$ & 90 & 10 & \\
\hline \multirow{3}{*}{ WRB } & & $1970 \mathrm{~s}$ & 23.92 & 76.08 & \multirow{3}{*}[15]{} \\
\hline & & $1980 \mathrm{~s}$ & 25.17 & 74.83 & \\
\hline & & $1990 \mathrm{~s}$ & 48.50 & 51.50 & \\
\hline
\end{tabular}

Table 3. Contribution rates of human activities and climate change for SSL reduction.

\begin{tabular}{|c|c|c|c|c|c|}
\hline \multirow{2}{*}{ Study area } & \multicolumn{2}{|c|}{ Data } & \multirow{2}{*}{$\begin{array}{l}\text { Impact by human activities } \\
\qquad(\%)\end{array}$} & \multirow{2}{*}{$\begin{array}{l}\text { Impact by climate change } \\
\qquad(\%)\end{array}$} & \multirow{2}{*}{ Reference } \\
\hline & Benchmark & Changed period & & & \\
\hline YRB & & & 70 & 30 & {$[36]$} \\
\hline YRB & \multicolumn{2}{|c|}{ 2000-08 } & 54.0 & 46.0 & {$[34]$} \\
\hline YRB & \multicolumn{2}{|c|}{$1979-2008$} & 81.0 & 19.0 & {$[38]$} \\
\hline YRB & $1919-86$ & $2000-12$ & $72.2-76.5$ & & {$[35]$} \\
\hline YRB & & $1980-89$ & 71.9 & 28.1 & {$[37]$} \\
\hline \multirow{2}{*}{ WRB } & \multirow{2}{*}{$1956-70$} & $1971-92$ & $59.78-83.75$ & $16.25-40.22$ & \multirow{2}{*}{ [8] } \\
\hline & & $1993-2010$ & $71.57-88.31$ & $11.69-28.43$ & \\
\hline \multirow{3}{*}{ WRB } & & $1970 \mathrm{~s}$ & 43.86 & 56.14 & \multirow{3}{*}[15]{} \\
\hline & & $1980 \mathrm{~s}$ & 4.49 & 95.51 & \\
\hline & & $1990 \mathrm{~s}$ & 42.86 & 57.14 & \\
\hline
\end{tabular}

on the varied water runoff and SSL, and the ratios are temporally varied. Former researchers have analyzed the contributions of human activities and climate change [5, 33-39], as shown in Tables 2 and 3.

4) Elevation at Tongguan.

The changed runoff and SSL in the WRB may also influence the elevation of the Tongguan. The relationship between changes in runoff and elevation at Tongguan are [40]:

$$
Z_{t g}=-0.0005 W_{T G}+328.95\left(R^{2}=0.65\right)
$$

$$
\begin{gathered}
Z_{t g}=-0.00061 W_{T G}{ }^{\prime}+328.37\left(R^{2}=0.62\right) \\
\Delta Z_{t g}=0.049-0.016 \Delta E-5 \times 10^{-5} \Delta E^{2}\left(R^{2}=0.72\right)
\end{gathered}
$$

...where $Z_{\mathrm{tg}}$ is the elevation of Tongguan measured at the end of the flood season (m), $W_{\mathrm{TG}}$ is the annual runoff at Tongguan station $\left(10^{9} \mathrm{~m}^{3}\right) ; W_{\mathrm{TG}}$, is the runoff in the flood season at Tongguan station $\left(10^{9} \mathrm{~m}^{3}\right)$; and $E$ is the annual stream energy per unit length $\left(10^{9} \mathrm{~J} / \mathrm{m}\right)$. 
5) Deposition in the Lower Wei River.

The accumulated deposition in the Lower Wei River can be estimated as [41]:

$$
\begin{aligned}
& \operatorname{Dep}_{S(W)}=0.6973 Z_{t g}-217.03 \quad R^{2}=0.62 \\
& \text { (1973-1991) } \\
& D e p_{S(W)}=1.7242 Z_{t g}-551.92 \quad R^{2}=0.85
\end{aligned}
$$

(1992-2000)

...where $D e p_{S(W)}$ represents deposition in the lower channel of the Wei River $\left(10^{8} \mathrm{~m}^{3}\right)$.

6) Deposition in the LYR.

Based on data in 1950-97, the annual deposition and deposition in flood season in the LYR can be estimated as $[26,28]$ :

$$
\begin{gathered}
\operatorname{Dep}_{S(3)}=a_{1} W_{S(3)}-b_{1} W_{(3)}+c_{1} \\
\operatorname{Dep}_{S(3)}{ }^{\prime}=a_{2} W_{S(3)}{ }^{\prime}-b_{2} W_{(3)}{ }^{\prime}+c_{2}
\end{gathered}
$$

...where $D e p_{S_{(\beta)}}$ is the annual deposition in the reach of Sanmenxia-Lijin $\left(10^{8} t\right), W_{S(\mathcal{B})}$ is annual SSL with unit of $10^{8} \mathrm{t}$, and $W_{(\beta)}$ is annual river flow with unit of $10^{8} \mathrm{~m}^{3}$. The input of annual water runoff or SSL to the LYR can be calculated as the sum of data measured at Sanmenxia station on the Yellow River, at Heishiguan station on the Yiluohe River, and at Xiaodong station on the Qinhe River [26]. The values of $a_{1}, b_{1}$, and $c_{1}$ are $0.507,0.0192$, and 3.84, respectively. $D e p_{S_{(3)}}{ }^{\prime}$ is deposition during flood season in the reach of Tiexie-Lijin $\left(10^{8} \mathrm{t}\right)$; and $W_{B \beta}{ }^{\prime}$ and $W_{S_{(3)}}$ ' are the total water runoff and SSL during flood season of the LYR (estimated by summing up data at Sanmenxia, Heishiguan, and Xiaodong), with unit of $10^{8} \mathrm{~m}^{3}$ and $10^{8} \mathrm{t}$. Subscript 3 represents the third reach, the LYR. The values of $a_{2}, b_{2}$, and $c_{2}$ are $0.523,0.025$, and 2.352 , respectively.

When the incoming runoff and SSL changed, the deposition in the LYR changed correspondingly:

$$
\begin{gathered}
\Delta \operatorname{Dep}_{S(3)}=a_{1} \Delta W_{S(3)}-b_{1} \Delta W_{(3)} \\
\Delta D e p_{S(3)}{ }^{\prime}=a_{2} \Delta W_{S(3)}^{\prime}-b_{2} \Delta W_{(3)}^{\prime}
\end{gathered}
$$

On behalf of maintaining the quasi state of the lower channel $\left(\Delta D e p_{S(\mathcal{1})}=0\right.$ or $\left.D e p_{S(\beta)}{ }^{\prime}=0\right)$, decreased sediment load may also lead to increased water amount available in the lower channel. This means that sediment load entering the lower channel may be transported into the sea by flood. The ratio of $a_{1} / b_{1}$ and $a_{2} / b_{2}$ are 26.4 (annual) and 20.9 (food season), respectively. This indicates that the capacity of transporting sediment into sea by foods in food-season is larger than that of foods in the non-food season.

\section{Data Collection}

Data used herein are data measured in the WRB. There are three controlling stations, Zhangjiashan Hydrology Station (the controlling station of the Jing River), Zhuangtou Hydrology Station (the controlling station of the Beiluo River) and Huaxian Hydrology Station (the controlling station of the upper drainage area of the Wei River). At these three stations, daily data of water elevation, discharge, and SSC are measured according to Chinese national standard criteria. Data were published as "hydrological records" by the hydrology bureau of the YRCC. More than 80 years of annual precipitation, annual runoff, and annual SSL measured are collected and analyzed. Besides, data for irrigation, flood protection, and water stored in reservoirs and also water diverted from the river to basin are collected. Then all the natural runoff of these three hydrology stations can be estimated.

\section{Results and Discussion}

Firstly, the temporal variation of the runoff and SSL from the WRB are analyzed. Then the effects of changed runoff and SSL on the WRB and the LYR are estimated. For equations in flood season, i.e., Eqs. (6), (11), and (13), the relationships between independent variable and dependent variable are similar to that of the whole year, with slightly changed coefficients. So, the effect of changed elevation at the Tongguan Hydrology Station and deposition in the LWR and LYR during flood season are no longer analyzed.

\section{Temporal Variation of Natural and Measured Runoff and SSL}

The mass curve of anomaly values describes the changed process of a particular parameter by comparing it with the mean value of that parameter over the whole study period. So the accumulative anomaly was used to detect the changing tendency of precipitation, SSL, runoff, suspended sediment concentration, and vaportranspiration [42].

The changed processes of natural and measured series of the WRB are shown in Fig. 3. The changing points of natural runoff were in 1968 and 1983 (Fig. 3a). The mean runoffs before 1968 were smaller than the mean for the whole period, but after 1983 were higher than the mean of the whole period. For the measured SSL, the changing points of measured SSL were in 1976 and 1995. This indicates that mean annual SSL before 1976 were smaller than the mean for the whole period, but that after 1995 they were higher than the mean of the whole period. The mass curve of measured runoff and natural SSL are complex with many short-time up and down phases.

Based on the changing points of mass curves of anomalies of measured runoff and natural SSL, several stages can be detected (Fig. 3b). In the first stage (1956 to 1967), mean measured runoff and SSL were 

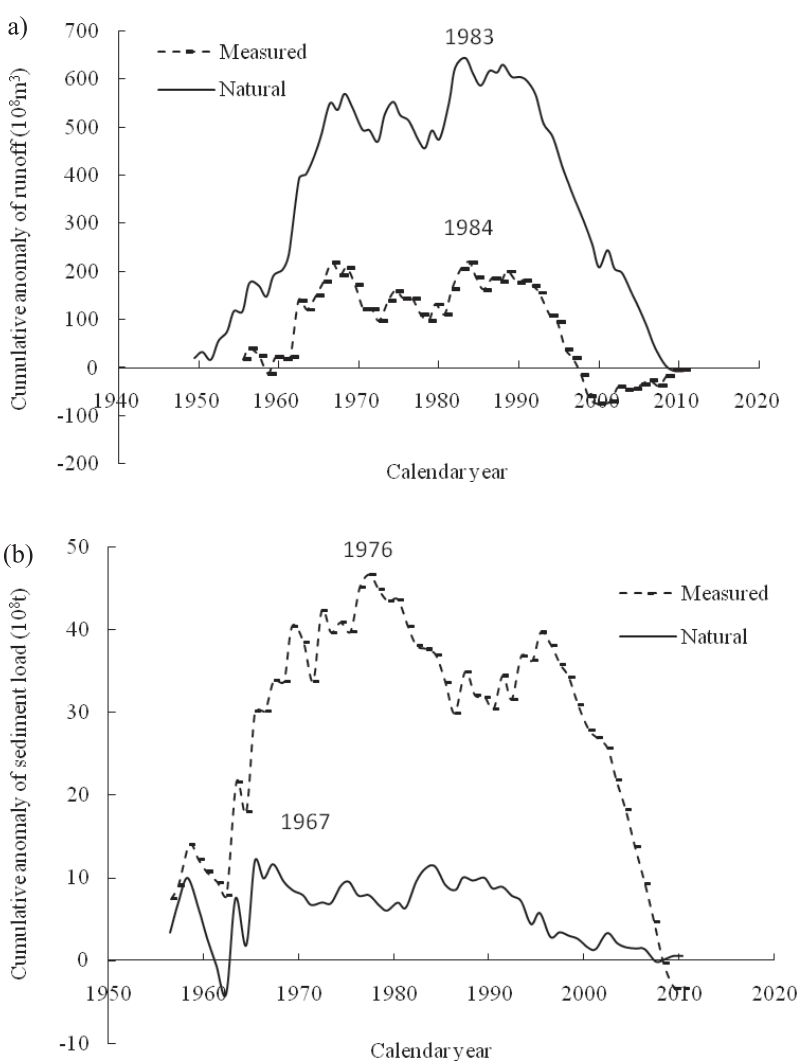

Fig. 3. Cumulative anomaly test results of natural and measured series: a) runoff, b) suspended sediment load.

$125 \times 10^{8} \mathrm{~m}^{3}$ and $8.88 \times 10^{8} \mathrm{t}$, respectively, but the mean values for the whole process (with many short-time up and down phases) were $110 \times 10^{8} \mathrm{~m}^{3}$ and $8.10 \times 10^{8} \mathrm{t}$, respectively. Mean measured runoff and SSL in the second stage (1968 to 1984 ) and third stage (after 1985) were $111 \times 10^{8} \mathrm{~m}^{3}$ and $102 \times 10^{8} \mathrm{~m}^{3}$, and $8.17 \times 10^{8} \mathrm{t}$ and $7.69 \times 10^{8} \mathrm{t}$, respectively. For the first stage, the average runoff and SSL increased about $13.6 \%$ and $9.6 \%$, respectively. For the second stage, the average runoff and SSL increased about $1 \%$ and $1 \%$, respectively. For the third stage, the average runoff and SSL decreased about $7 \%$ and $5 \%$, respectively.

Decadal impacts by human activities are listed in Tables 2 and 3. So the decadal variation of runoff and SSL are also analyzed. The first period (1960-69) is viewed

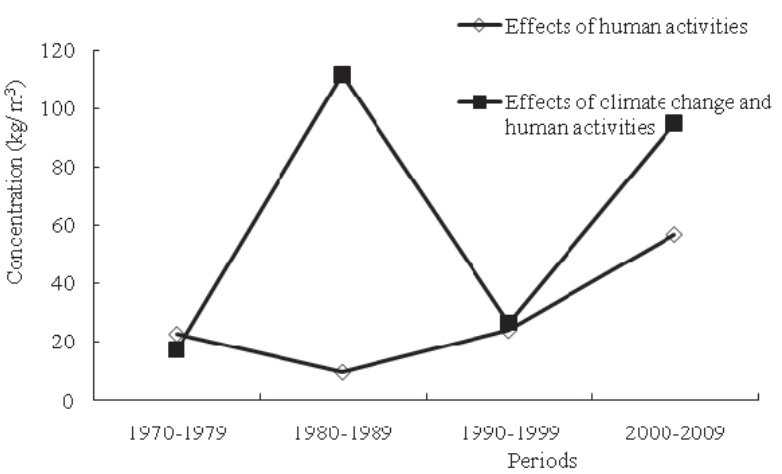

Fig. 4. Correlations between decreased runoff and SSL by human activities and climate change.

as benchmark herein. The following four periods are years between 1970-1979, 1980-1989, 1990-1999 and 2000-2009.

With collected natural and measured data listed above, the discrepancy caused by human activities and climate change can be estimated by Eqs (1-2). Then Eqs (3-4) can be used to estimate the contribution by human activities with ratios (ratios by references [9] and [15]). The contribution ratio after 2000 used is data by [8] listed in Table 3. The effects of climate change and human activities are listed in Table 4 and Fig. 4, which shows that, for combined effects of climate change and human activities, the correlations between decreased runoff and SSL during 1980-1989 and 2000-2009 are different than other periods, with much more decreased SSL and relatively less runoff. The concentrations of decreased runoff and SSL during 1980-1989 and 2000-2009 are about $100 \mathrm{~kg} / \mathrm{m}^{3}$, and the concentrations during other periods are about $25 \mathrm{~kg} / \mathrm{m}^{3}$.

For the effects of human activities, the amounts of decreased runoff and SSL during 2000-2009 are the largest, with amounts of $48.94 \times 10^{8} \mathrm{~m}^{3} / \mathrm{yr}$ and $3.71 \times 10^{8} \mathrm{t} / \mathrm{yr}$, respectively. More importantly, the correlation between decreased runoff and SSL during 2000-2009 changed. The concentration by human activities during $1980-1989$ is the smallest $\left(10 \mathrm{~kg} / \mathrm{m}^{3}\right)$, and the concentration during 2000-2009 is the largest $\left(57 \mathrm{~kg} / \mathrm{m}^{3}\right)$.

Table 4. Decadal variations of runoff and SSL by human activities and climate change.

\begin{tabular}{|c|c|c|c|c|c|c|}
\hline \multirow[b]{2}{*}{ Periods } & \multicolumn{4}{|c|}{ Total } & \multicolumn{2}{|c|}{ Human activities } \\
\hline & $\begin{array}{c}\text { Amount of } \\
\text { decreased runoff } \\
\left(10^{8} \mathrm{~m}^{3} / \mathrm{yr}\right)\end{array}$ & $\begin{array}{c}\text { Impact by } \\
\text { human activities } \\
(\%)\end{array}$ & $\begin{array}{c}\text { Amount of } \\
\text { decreased SSL } \\
\left(10^{8} \mathrm{t} / \mathrm{yr}\right)\end{array}$ & $\begin{array}{c}\text { Impact by } \\
\text { human activities } \\
(\%)\end{array}$ & $\begin{array}{l}\text { Decreased } \\
\text { runoff } \\
\left(10^{8} \mathrm{~m}^{3} / \mathrm{yr}\right)\end{array}$ & $\begin{array}{c}\text { Decreased SSL } \\
\quad\left(10^{8} \mathrm{t} / \mathrm{yr}\right)\end{array}$ \\
\hline $1960-69$ & -0.94 & & -0.03 & & & \\
\hline $1970-79$ & 34.05 & 0.64 & 0.58 & 0.44 & 24.59 & 0.56 \\
\hline $1980-89$ & 22.92 & 0.72 & 2.56 & 0.05 & 16.50 & 0.16 \\
\hline 1990-99 & 41.59 & 0.47 & 1.10 & 0.43 & 19.55 & 0.47 \\
\hline 2000-09 & 54.37 & 0.90 & 5.15 & 0.72 & 48.94 & 3.71 \\
\hline
\end{tabular}


Table 5. Changed elevation at Tongguan Hydrology Station.

\begin{tabular}{|c|c|c|c|}
\hline Periods & $\begin{array}{c}\text { Changed } \\
\text { elevation at } \\
\text { Tongguan } \\
(\mathrm{m} / \mathrm{yr})\end{array}$ & $\begin{array}{c}\text { Changed elevation } \\
\text { at Tongguan by } \\
\text { human activities } \\
(\mathrm{m} / \mathrm{yr})\end{array}$ & Ratio \\
\hline $1970-1979$ & -0.019 & -0.012 & 0.63 \\
\hline $1980-1989$ & -0.011 & -0.008 & 0.73 \\
\hline $1990-1999$ & -0.021 & -0.010 & 0.48 \\
\hline $2000-2009$ & -0.027 & -0.024 & 0.89 \\
\hline
\end{tabular}

\section{Effects on the Wei River}

According to Eqs (5) and (7), the elevation of the Tongguan Hydrology Station can be estimated. The Tongguan elevation is highly influenced by changed runoff after 2000 , with a value of $-0.027 \mathrm{~m} / \mathrm{yr}$. The effect of human activities on Tongguan elevation in the fifth period (2000-2009) is the largest, and the value is about $-0.024 \mathrm{~m} / \mathrm{yr}$, which is about $89 \%$ of the total changed elevation.

The changed deposition in the LWR can be estimated by Eqs (8-9), as shown in Table 6 and Fig. 5. It shows that the deposition in the LWR by human activities counts for about $-0.042 \times 10^{8} \mathrm{t} / \mathrm{yr}$, while the changed deposition in the LWR is about $-0.047 \times 10^{8} \mathrm{t} / \mathrm{yr}$. As the compound effects of human activities and climate change in the WRB,

Table 6. Changed deposition in the LWR.

\begin{tabular}{|c|c|c|c|}
\hline Periods & $\begin{array}{c}\text { Changed } \\
\text { deposition in } \\
\text { the LWR } \\
\left(10^{8} \mathrm{t} / \mathrm{yr}\right)\end{array}$ & $\begin{array}{c}\text { Changed } \\
\text { deposition by } \\
\text { human activity } \\
\left(10^{8} \mathrm{t} / \mathrm{yr}\right)\end{array}$ & Ratio \\
\hline $1970-1979$ & -0.013 & -0.009 & 0.69 \\
\hline $1980-1989$ & -0.008 & -0.006 & 0.75 \\
\hline $1990-1999$ & -0.034 & -0.016 & 0.47 \\
\hline $2000-2009$ & -0.047 & -0.042 & 0.89 \\
\hline
\end{tabular}

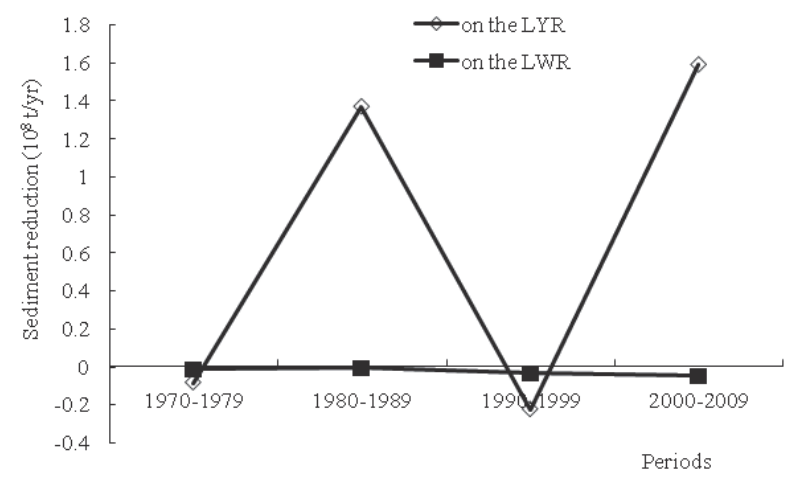

Fig. 5. Changed depositions in the LYR and LWR by climate change and human activities.

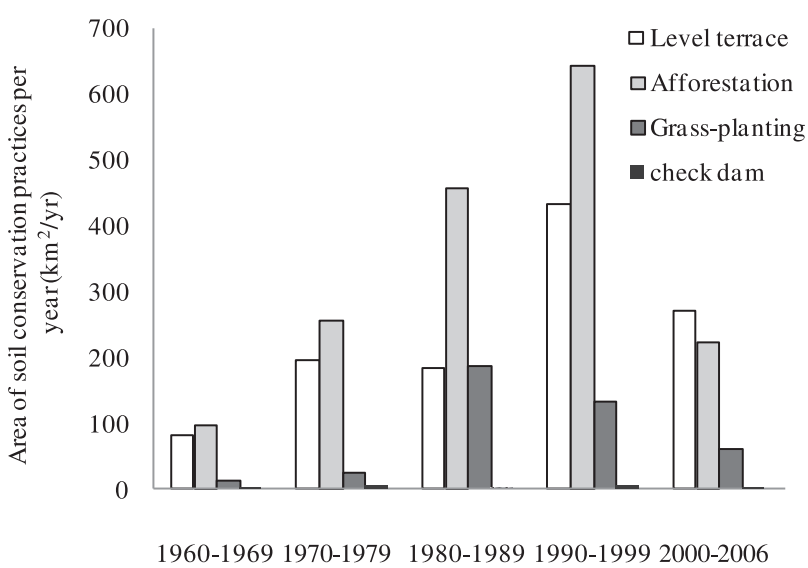

Fig. 6. Area of soil conservation practices in the WRB after 1960.

the amount of deposition decreased in the LWR during 2000-2009 is about three times that of the decrease during 1970-1979. For the effects of human activities in the WRB on the deposition in the LWR, the amount of deposition decreased in the LWR during 2000-2009 is about five times the decrease during 1970-1979.

The area with soil conservation practices during the period of 2000-2009 is almost the same as that in 1970-1979, while the ratios of controlling the area of the check dams on the whole conservation practices are about $0.83 \%$ and $0.16 \%$, respectively (Fig. 6). And the amounts of deposition decreased in the LWR for these two periods are $-0.009 \times 10^{8} \mathrm{t} / \mathrm{yr}$ and $-0.016 \times 10^{8} \mathrm{t} / \mathrm{yr}$, respectively, and the contributions by human activities in these two periods are $89 \%$ and $69 \%$, respectively. The sediment reduction effects on the LWR during 1970-1979 and 1990-1999 are about 18 t/ha and 13 t/ha, respectively (Fig. 7). The sediment reduction effect on the LWR during 2000-2009 and 1980-1989 are about $76 \mathrm{t} / \mathrm{ha}$ and $7 \mathrm{t} / \mathrm{ha}$, respectively. So the effect of soil conservation practices on deposition in the LWR during the fifth period is about four times that of the secondary period.

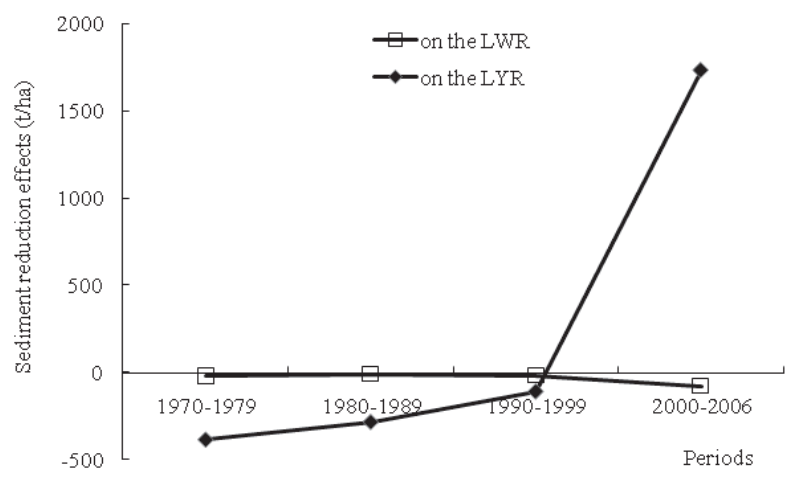

Fig. 7. Sediment reduction effects of human activities on the LWR and LYR. 
Table 7. Changed deposition in the LYR.

\begin{tabular}{|c|c|c|c|}
\hline Periods & $\begin{array}{c}\text { Changed } \\
\text { deposition in } \\
\text { the LYR } \\
\left(10^{8} \mathrm{t} / \mathrm{yr}\right)\end{array}$ & $\begin{array}{c}\text { Changed deposition } \\
\text { in the LYR by } \\
\text { human activities } \\
\left(10^{8} \mathrm{t} / \mathrm{yr}\right)\end{array}$ & Ratio \\
\hline $1970-1979$ & -0.084 & -0.184 & 2.19 \\
\hline $1980-1989$ & 1.371 & -0.233 & -0.17 \\
\hline $1990-1999$ & -0.225 & -0.129 & 0.57 \\
\hline $2000-2009$ & 1.592 & 0.963 & 0.60 \\
\hline
\end{tabular}

\section{Effects on the Lower Yellow River}

The changed runoff and SSL in the WRB may also affect the fluvial process of the LYR, which can be estimated by Eqs (12-13). Deposition in the LYR decreased during the period of 1970-1979 and 1990-1999, while deposition in the LYR increased during the period of 1980-1989 and 2000-2009 (Table 7). The contribution ratios by human activities on the changed deposition in the LYR decreased from 2.19 to 0.6 from the secondary period to the fifth period. And the effects of human activities between these two periods are about flive times. As mentioned before, the area of soil conservation practices in these two periods are almost the same. However, the effects of human activities in the WRB on the deposition in the LYR are opposite. During the second period (1970-1979), human activities in the WRB may lead to decreased deposition in the LYR, and it may lead to increased deposition in the LYR during the fifth period (2000-2009). The main reason for increased deposition in the LYR during years after 2000 is the larger amount of decreased runoff than that of SSL. One thing that should be pointed out is some equations used are extended to years after 2000, i.e., Eq. (9), which may lead to a certain discrepancy.

According to the area of soil conservation practices, the sediment reduction effects on the LYR are different from that in the LWR (Eqs 5-9), as deposition in the LYR (Eqs 10-11) is influenced by both the SSL and water runoff. And the sediment reduction effect on the LYR during 2000-2009 is about 1,734 t/ha. Besides, the effects of water and soil reduction by human activities on the LWR and LYR have increased dramatically during 2000-2009, on behalf of correlation between decreased runoff and SSL (Fig. 7).

\section{Influence of the Planned Reservoir}

According to the layout of the Jing River Basin, the planned Dongzhuang Reservoir may be located on the stem channel of the Jing River. The reservoir may trap a large amount of sediment eroded from the Jing River Basin. The distance between planned reservoir and the Zhangiiashan Hydrology Station is about $29 \mathrm{~km}$. The controlling drainage area of the reservoir is approximately $4.31 \times 10^{4} \mathrm{~km}^{2}$, which may count for about $95 \%$ of Jing River basin and $40.5 \%$ of the controlling area of Huaxian Hydrology Station.

Firstly, the runoff and SSL at these four controlling stations are listed in Table 8, which are the measured annual data. These data are viewed as measured data before the planned reservoir. After the operation of the planned reservoir, the reservoir may reduce the amount of sediment entering to the LWR and corresponding deposition in the lower channel. The reservoir may trap about $0.5 \times 10^{8} \mathrm{t}$ sediment in each year, and the corresponding runoff is about $9.16 \times 10^{8} \mathrm{~m}^{3}$ [43]. So, for data after the operation of the planned reservoir, the total runoff and SSL entering the LWR may be decreased accordingly, as shown in Table 9.

Deposition in the LWR may decrease $0.099 \times 10^{8} \mathrm{t} /$ $\mathrm{yr}$, and the deposition in the LYR may be $0.078 \times 10^{8} \mathrm{t} / \mathrm{yr}$. The controlling area of the planned reservoir is about $4.31 \times 10^{4} \mathrm{~km}^{2}$, and the sediment reduction effects of per controlled area on the deposition in the LWR and LYR are $2.29 \mathrm{t} / \mathrm{ha}$ and $1.81 \mathrm{t} / \mathrm{ha}$, respectively. For the water and soil conservation practices (level terrace, afforestation, grass-planting, check dam) during 1970-1979 and 20002006, the sediment reduction effects of per controlled area on the deposition in the LWR are $18 \mathrm{t} / \mathrm{ha}$ and $76 \mathrm{t} / \mathrm{ha}$, respectively. For the planned reservoir, sediment reduction in the LYR is smaller than that of the LWR. However, the sediment decrease caused by water and soil conservation practices in the LYR is larger than that of the LWR, except the period of 2000-2009.

\section{Implication on Drainage Management}

There are other empirical formula to estimate the relationship between deposition in the LYR and runoff and SSL entering the LYR. The relationship between sediment reduction in the upland and deposition in the LYR can be expressed as [11-12]

$$
\operatorname{Dep}_{S(3)}=0.7 \Delta W_{S(3)}
$$

Table 8. Annual data of runoff and SSL in controlling stations.

\begin{tabular}{|c|c|c|c|c|c|}
\hline & Xianyang & Zhangtou & Zhangjiashan & South Mountain Tributary & Water stage at Tongguan $(\mathrm{m})$ \\
\hline Runoff $\left(10^{8} \mathrm{~m}^{3}\right)$ & 34.21 & 7.40 & 13.44 & 5.47 & 326.38 \\
\hline SSL $\left(10^{8} \mathrm{t}\right)$ & 0.94 & 0.68 & 2.03 & -- & -- \\
\hline
\end{tabular}


Another way of estimating annual deposition and deposition in flood season in the LYR by water runoff from Toudaoguai and SSL from drainage area between Tongguan and Longmen, and the equations are expressed as [27]:

$$
\begin{gathered}
\operatorname{Dep}_{S(3)}=0.839 W_{S(T-L)}-0.398 W_{(T)} \\
D e p_{S(3)}{ }^{\prime}=0.887 W_{S(T-L)}{ }^{\prime}-0.130 W_{(T)}{ }^{\prime}
\end{gathered}
$$

...where $D e p_{S(3)}{ }^{\prime}$ and $D e p_{S(\beta)}$ are the deposition in flood season and annual deposition in the Sanmenxia-Lijin reach $\left(10^{4} \mathrm{t}\right) ; W_{(T)}{ }^{\prime}$ and $W_{(T)}$ are the water runoff in flood season and the annual value from drainage area upper Toudaoguai $\left(10^{8} \mathrm{~m}^{3}\right)$, respectively; and $W_{S(T-L)}{ }^{\prime}$ and $W_{S(T-L)}$ are the SSL in flood season and the annual value from drainage area between Toudaoguai and Longmen $\left(10^{4} \mathrm{t}\right)$, respectively. The difference of coeflicients of the second term $\left(W_{(T)}\right.$ and $\left.W_{(T)}{ }^{\prime}\right)$ on the right hand side of Eqs (15-16) indicates the influence of water runoff from the upper Yellow River in non-flood season on the deposition in LYR. The relationship between SSL from the middle drainage area and deposition in the LYR are 0.839 (annual) and 0.887 (flood season), respectively, while the value in Eq. (14) is 0.7. However, the decadal trend of deposition changed in the LYR may not be changed.

For a river channel, matched SSL and runoff may benefit the channel, as all SSL can be transported by the runoff and no more deposition occurred in the stem channel. This means that, in order to maintain a quasiequilibrium state of the river channel, SSL should have decreased with a certain proportion of decreased runoff, with a formula of $\Delta W=f \Delta W_{S}$. As sediment load entering the channel needs a certain amount of water runoff to carry into sea. If the amount of $\Delta W$ is larger than that of $f \Delta W_{S}$, there may be erosion in the channel. If the amount of $\Delta W$ is smaller than that of $f \Delta W_{S}$, there may be deposition in the channel. In order to maintain the lower reach in the status quo, the value of $f$-parameter in the relationship of $\Delta W=f \Delta W_{S(3)}$. adopted in references [11-12] are 20 and 16 , respectively. This means that the amount of water runoff is about $16-20 \mathrm{~m}^{3}$ to transport a unit ton of sediment into the sea, with no more deposition occurring

Table 9. Annual data of runoff and SSL in the whole WRB.

\begin{tabular}{|c|c|c|c|c|}
\hline Scenario & $\begin{array}{c}\text { Runoff } \\
\left(10^{8} \mathrm{~m}^{3} /\right. \\
\mathrm{yr})\end{array}$ & $\begin{array}{c}\mathrm{SSL} \\
\left(10^{8} \mathrm{t} / \mathrm{yr}\right)\end{array}$ & $\begin{array}{c}\text { Deposition } \\
\text { in the } \\
\text { LWR } \\
\left(10^{8} \mathrm{t} / \mathrm{yr}\right)\end{array}$ & $\begin{array}{c}\text { Deposition } \\
\text { in the LYR } \\
\left(10^{8} \mathrm{t} / \mathrm{yr}\right)\end{array}$ \\
\hline $\begin{array}{c}\text { Pre- } \\
\text { reservoir }\end{array}$ & 60.52 & 3.65 & 0.224 & -- \\
\hline $\begin{array}{c}\text { After- } \\
\text { reservoir }\end{array}$ & 51.36 & 3.15 & 0.125 & -- \\
\hline $\begin{array}{c}\text { Influence } \\
\text { by the } \\
\text { reservoir }\end{array}$ & -- & -- & 0.099 & 0.078 \\
\hline
\end{tabular}

in the lower stem channel. With a unit ton of sediment reduction from the upper drainage area, the amount of water available for the lower channel can increase $16-20 \mathrm{~m}^{3}$. The values of $f$-parameter shown in Eqs (12-13) are 26.4 (annual) and 20.9 (flood season), respectively.

On behalf of maintaining the lower reach in the status quo, more sediment loading entering the lower reach means more water 'wasted' to transport sediment into the sea. This means that the decreased sediment load from the upper watershed may benefit the water shortages, while decreased water runoff may be a disadvantage of the water shortage. Substitute Eq. (14) into Eqs (12) and (13), and the values of $f$-parameter in $\Delta W=f \Delta W_{S(3)}$ are -10 and -7 , respectively. These values are different from the ratio of 16-26, which also indicates a deposition trend in the LYR. And the quasi equilibrium state of the lower Yellow River rarely occurrs in reality $\left(\Delta D e p_{S(3)} \neq 0\right)$. One important thing should be pointed out: the statement herein ignored the difference between flood events and non-flood periods during the year, and this is a statistical analysis based on inter-annual data. Besides, the inner assumption is that the incoming water and SSL in the Lower Yellow River is only affected by $\Delta W$ and $\Delta W_{S}$ in the Wei River, and the water runoff and SSL from the other drainage area of the Yellow River is not considered in the analysis.

\section{Conclusions}

Based on measured and natural runoff and SSL in the WRB, the effects of human activities in the WRB on the LWR and LYR are analyzed. Conclusions are:

1. As the compound effects of human activities and climate change affect the WRB, the amount of decreased deposition in the LWR during 2000-2009 is about three times th decrease during 1970-1979.

2. For the effects of human activities in the WRB on the deposition in the LWR, the effect during 2000-2009 is about four times that of the period of 1970-1979.

As the compound effects of human activities and climate change in the WRB, deposition in the LYR decreased during the period of 1970-1979 and 1990-1999, while deposition in the LYR increased during the period of 1980-1989 and 2000-2009. And the effects of human activities in the WRB on the LYR between these two periods are about five times. Analysis shows that decreased runoff and SSL from the WRB is not necessarily beneficial to the LYR on point of deposition.

3. For the planned reservoir, sediment reduction in the LYR is smaller than that of the LWR. And the sediment decrease caused by water and soil conservation practices in the LYR is larger than that of the LWR, except the period of 2000-2009. 


\section{Acknowledgements}

This research is supported by the National Natural Science Foundation of China (Nos. 2016YFC0402503 and 51579230), the National Key Basic Research Program (No. 2011CB403305), the National Key Technology R\&D Program of China (No. 2012BAB02B02), and National Natural Science Foundation of China (Nos. 41571005 and 51109198).

\section{References}

1. MIAO C.Y., NI J.R., BORTHWICK A.G.L. Recent changes of water discharge and sediment load in the Yellow River Basin, China. Prog Phys Geogr., 34, 541, 2010.

2. JIAO J., WANG Z., ZHAO G., WANG W., MU X. Changed in sediment discharge in a sediment-rich region of the Yellow River from 1955 to 2010: implications for further soil erosion control. J. Arid Land, 6 (5), 540, 2014.

3. LU X.X. Vulnerability of water discharge of large Chinese rivers to environmental changes: an over view. Region. Environ. Changes, 4, 182, 2004.

4. LU X. X., SIEW R.Y. Water discharge and sediment flux changes over the past decades in the Lower Mekong River: Possible impacts of the Chinese dams, Hydrol. Earth Syst. Sci., 10, 181, 2006.

5. WANG Y., DING Y.J., YE B.S., LIU F.J., WANG J., WANG J. Contributions of climate and human activities to changes in runoff of the Yellow and Yangtze rivers from 1950 to 2008. Sci. China Earth Sci., 56 (8), 1398, 2013.

6. DU J., SHI C.X. Effects of climatic factors and human activities on runoff of the Weihe River in recent decades. Quaternary International, 282, 58, 2012.

7. GUO Y., LI Z.J., AMO-BOATENG M., DENG P., HUANG P.N. Quantitative assessment of the impact of climate variability and human activities on runoff changes for the upper reaches of Weihe River. Stoch Environ Res Risk Assess, 28, 333, 2014.

8. CHANG J.X., LI Y.Y., WEI J., WANG Y.M., GUO A.J. Dynamic changes of sediment load and water discharge in the Weihe River, China. Environ Earth Sci, 75, 1042, 2016.

9. CHANG J.X., WANG, Y.M., ISTANBULLUOGLU, M., BAI, T., HUANG, Q., YANG, D.W., HUANG, S.Z. Impact of climate change and human activities on runoff in the Weihe River Basin, China. Quaternary International, 380, 169, 2015.

10. MA Y., QIN B.S., WANG H., ZHAO J.X. Variations of water and sediment of the Weihe River and impact factors analysis. Soil Water Conserv. China, 8, 18, 2002 (In Chinese with English abstract).

11. RAN D.C. Water and sediment variation and ecological protection measures in the middle reach of the Yellow River. Resour. Sci., 28, 93, 2006 (In Chinese with English abstract).

12. RAN D.C., LIU B., WANG H. Analysis on sediment reduction of the Yellow River through soil and water conservation measures. SWCC, 10, 35, 2002 (In Chinese with English abstract).

13. RAN H.R., LI G.S., CUI L.L., HE L. Multi-scale variability of water discharge and sediment load into the Bohai Sea from 1950 to 2011. J. Geogr. Sci., 25 (1), 85, 2015.

14. ZHANG Y.Z., HUANG C.C., PANG J.L., ZHA X.C., ZHOU Y.L., YIN S.Y., WANG J. Comparative study of the modern flood slackwater deposits in the upper reaches of Hanjiang and Weihe River Valleys, China. Quaternary International, 282, 184, 2012.

15. WANG H., QIN B.S., MA Y., ZHAO J.X. Effect of water and soil conservation practices in the Wei River Basin. Yellow River, 23 (2), 18, 2001 (In Chinese with English abstract).

16. LIU R.X. Benefits of decreasing runoff and sediment and trend forecast of runoff and sediment changes in Weihe Watershed. Bulletin of Soil and Water Conservation, 13 (6), 17, 1993 (In Chinese with English abstract).

17. ZHU J.L., GAO P., GEISSEN V., MAROULIS J., RITSEMA C.J., MU X.M., ZHAO G.J. Impacts of rainfall and land use on sediment regime in a semi-arid region: Case study of the Wuqi Catchment in the Upper Beiluo River basin, China. Arid Land Research and Management, 29, 1, 2015.

18. SHI H.Y., WANG G.Q. Impacts of climate change and hydraulic structures on runoff and sediment discharge in the middle Yellow River. Hydrol. Process., 29, 3236, 2015.

19. LI T.H., GAO Y. Runoff and Sediment Yield Variations in Response to Precipitation Changes: A Case Study of Xichuan Watershed in the Loess Plateau, China. Water, 7, 5638,2015

20. ZHOU Y.Y., SHI C.X., FAN X.L., SHAO W.W. The influence of climate change and anthropogenic activities on annual runoff of Huangfuchuan basin in northwest China. Theor, Appl. Climatol., 120, 137, 2015.

21. ZHAO G.J., TIAN P., MU X.M., JIAO J.Y., WANG F., GAO P. Quantifying the impact of climate variability and human activities on stream flow in the middle reaches of the Yellow River basin, China. J. Hydrol., 519, 387, 2014.

22. LIU F., CHEN S.L., PENG J., CHEN G.Q. Temporal variability of water discharge and sediment load of the Yellow River into the sea during 1950-2008. J. Geogr. Sci., 21 (6), 1047, 2011.

23. WANG G., XU A.Y., ZHANG S. The influence of land use patterns on soil erosion and water quality in the river system at multiple spatial scales. Hydrol. Process., 28, 5259, 2014.

24. OUYANG C.B., WANG W.L., TIAN Y., TIAN S.M. Evaluation on the variation of water-sediment and human activities in the He-Long Reach of the Yellow River over the past 60 years. Journal of Sediment Research, 4, 55, 2016.

25. ZHAO G.J., LI E.H., MU X.M., WEN Z.M., RAYBURG S., TIAN P. Changing trends and regime shift of streamflow in the Yellow River basin. Stochastic Environmental Research and Risk Assessment, 29, 1331, 2015.

26. XU J.X. Effect of human activities on overall trend of sedimentation in the Lower Yellow River, China. Environmental Management, 33 (5), 637, 2004.

27. XU J.X. Sedimentation and sediment transport in Lower Yellow River as influenced by coupling of water and sediment yield in upper drainage basin. Journal of Sediment Research, 3, 49, 2011 (In Chinese with English abstract).

28. WU B.S., ZHANG Y.F., SHEN G.Q. Water and sediment conditions for the main channel of the Yellow River. The Yellow River Water Conservancy Press: Zhengzhou, China, 2010.

29. ZHANG X.C., PAN Y.M. Investigation and Assessment of Water Resources in the Yellow River. Publishing House of Yellow River Water Conservancy: Zhengzhou, China, 50, 2006 (In Chinese).

30. KUANG J., ZHANG X.C. Yellow River water resources and the concerned series consistency processing. Journal of China Hydrology, 26 (6), 6, 2006 (In Chinese with English abstract).

31. DU J., SHI C.X. Effects of climatic factors and human activities on runoff of the Weihe River in recent decades. Quaternary International, 282, 58, 2012. 
32. GAO P.X., MU X.M., WANG F., LI R. Changed in stream flow and sediment discharge and the response to human activities in the middle reaches of the Yellow River. Hydrology and Earth System Sciences, 15, 1, 2011.

33. ZHANG Y.Z., HUANG C.C., PANG J.L., ZHA X.C., ZHOU Y.L., YIN S.Y., WANG J. Comparative study of the modern flood slackwater deposits in the upper reaches of Hanjiang and Weihe River Valleys, China. Quaternary International, 282, 184, 2012.

34. MIAO C., NI J., BORTHWICK A.G.L., YANG L. A preliminary estimate of human and natural contributions to the changes in water discharge and sediment load in the Yellow River. Glob. Planet. Chang., 76 (3-4), 196, 2011.

35. YAO W.Y., XIAO P.Q., SHEN Z.Z., WANG J.H., JIAO P. Analysis of the contribution of multiple factors to the recent decrease in discharge and sediment yield in the Yellow River Basin, China. J. Geogr. Sci., 26 (9), 1289, 2016.

36. WANG H.J., YANG Z.S., SAITO Y., LIU J.P., SUN X.X., WANG Y. Stepwise decreases of the Huanghe (Yellow River) sediment load (1950-2005): impacts of climate change and human activities. Glob Planet Change, 57, 331, 2007.

37. CHU C.J., LI Y.L. Variation of runoff and sediment and their driving factors of the Yellow River Mainstream in the past 60 Years. Journal of Soil and Water Conservation, 27 (5), 41-47+132, 2013 (In Chinese with English Abstract).
38. MU X.M. Dynamic changes of sediment discharge and the influencing factors in the Yellow River, China, for the recent 90 years. Clean: Soil, Air, Water, 40 (3), 303, 2012.

39. LIU Q., YANG Z., CUI B. Spatial and temporal variability of annual precipitation during 1961-2006 in Yellow River Basin, China. J. Hydrol., 361, 330, 2008.

40. WU B.S., WANG G.Q., WANG Z.Y., XIA J.Q. Effect of changes in flow runoff on the elevation of Tongguan in Sanmenxia Reservoir. Chinese Science Bulletin, 49 (15), 1658, 2004.

41. ZHANG G.G., WANG X.H., FEN M.Q., ZHAO K.Y., LI J.Z. Riverbed aggradations and main channel shrinkage in the Lower reach of the Weihe River. Journal of Sediment Research, 3, 35, 2003.

42. RAN D.C., ZHAO L.Y., ZHANG Z.P., LUO Q.H. A quantative study on the effect of soil and water conservation measures on slope rill erosion mitigation with different scale in the Loess Plateau. Shuili Xuebao, 41 (10), 1135, 2010 (In Chinese with English Abstract).

43. Report by Tsinghua University (TSU). Numerical simulation of the sedimentation in the lower Wei River, Report. 2016 [In Chinese]. 